\title{
Modifikasi Teknik Invigorasi untuk Meningkatkan Viabilitas dan Vigor Benih Jagung Manis (Zea mays Sacharata L.)
}

\author{
Modification of Invigoration Techniques to Increase Viability and Vigor of Sweet Corn \\ Seeds (Zea mays Sacharata L.)
}

\author{
Author(s): Aulia Zakia ${ }^{(1) *}$; Muhammad Bahrul Ulum ${ }^{(1)}$; Aniek Iriany ${ }^{(1)}$; Agus Zainudin ${ }^{(1)}$ \\ (1) Universitas Muhammadiyah Malang \\ * Corresponding author: auliazakia@umm.ac.id
}

\begin{abstract}
ABSTRAK
Penyimpanan benih yang salah, dapat menyebabkan deteriorasi, sehingga viabilitas dan Kata Kunci: vigor benih di lapangan rendah. Teknik invigorasi diterapkan sesuai dengan jenis benihnya. Penelitian ini bertujuan untuk mengetahui apakah media agar yang dicampur agar; dengan arang aktif dapat digunakan sebagai alternatif cara invigorasi benih Jagung manis. Penelitian dilaksanakan pada bulan Oktober-November 2019, bertempat di Laboratorium Benih Agronomi, Program Studi Agroteknologi, Fakultas Pertanian-Peternakan, Universitas Muhammadiyah Malang. Penelitian dilakukan pada benih Jagung manis varietas Talenta, menggunakan rancangan acak lengkap (RAL) sederhana. Modifikasi teknik invigorasi sebagai faktor perlakuan, terdiri atas Kontrol, benih ditumbuhkan dalam media pasir (A0), modifikasi media agar (A1), modifikasi media agar ditambah arang aktif (A2), modifikasi media agar yang ditumpuk/ benih diletakkan diantara media agar (A3), modifikasi media agar+arang aktif yang ditumpuk/ benih diletakkan diantara media agar+arang aktif (A4), matriconditioning menggunakan arang sekam (A5). Setiap perlakuan diulang sebanyak 3 kali. Hasil percobaan menunjukkan bahwa viabilitas dan vigor benih Jagung masing-masing meningkat sebesar 22,22 \% dan 19, $45 \%$. Modifikasi metode invigorasi menggunakan agar dan arang aktif dapat dijadikan sebagai alternatif perlakuan invigorasi terhadap benih Jagung.
\end{abstract}

\section{arang aktif; imbibisi; imbibition injury.}

\section{Keywords:}

activated charcoal;

agar;

imbibition;

imbibition injury.

\section{ABSTRACT}

Seed deterioration can because by wrong storage, resulting in low seed viability and vigor in the field. Invigoration techniques are applied according to the type of seed. This study aims to determine whether agar media prepared with activated charcoal can be used as an alternative way of invigorating sweet corn seeds. The research was conducted in October-November 2019, at the Agronomy Seed Laboratory, Agrotechnology Study Program, Faculty of Agriculture-Animal Husbandry, University of Muhammadiyah Malang. The research was conducted on the seeds of Talenta sweet corn, using a simple completely randomized design (CRD). Modification of the invigoration technique as a treatment factor, consisting of control, the seeds were grown in sand media (AO), modified agar media (A1), modified agar media added with activated charcoal (A2), modified agar media which were stacked/ seeds were placed between agar media (A3), modify the agar media + activated charcoal that is stacked/ the seeds are placed between the agar medium + activated charcoal (A4), the matriconditioning uses rice husk charcoal (A5). Each treatment was repeated 3 times. The experimental results showed that the viability and vigor of maize increased by $22.22 \%$ and $19.45 \%$, respectively. Invigoration method modification using agar and activated charcoal can be used as an alternative invigoration treatment for sweet corn seeds. 


\section{PENDAHULUAN}

Produksi benih Jagung Indonesia tahun 2017 sejumlah $12 \%$ dari total produksi Jagung nasional yaitu sebesar 603933 t (BSN, 2008; Kementan, 2013; Panikkai et al. 2017). Berdasarkan luas lahan yang yang terdapat di seluruh Indonesia, hanya $16 \%$ dari jumlah produksi benih yang digunakan tepat waktu selama durasi satu tahun (Panikkai, 2017). Hal ini menyebabkan masih banyak benih yang disimpan dan tidak terpakai sampai tahun berikutnya. Penyimpanan benih yang salah, dalam kondisi sub optimum bagi benih, dapat menyebabkan deteriorasi, sehingga viabilitas dan vigor benih di lapangan menjadi rendah (Koes \& Arief, 2010; Nuraini et al., 2018; Taini et al., 2019).

Performa benih rendah di lapangan dapat diatasi dengan memberikan perlakuan benih sebelum tanam. Salah satu teknik meningkatkan vigor benih adalah melalui invigorasi. Invigorasi dibedakan menjadi dua, yakni osmoconditioning matriconditioning (Khan \& Willy, 1992; Ilyas, 2012). Osmoconditioning dilakukan dengan menggunakan cairan berpotensial rendah, sedangkan matriconditioning dilakukan dengan menggunakan media padat yang dilembabkan (Ilyas et al., 2002; Zakia et al., 2017). Invigorasi benih Jagung melalui osmoconditioning dengan merendam benih Jagung selama 24 jam sebelum penanaman terbukti mampu mempercepat pertumbuhan kecambah dan meningkatkan vigor kecambah (Harris et al., 2004).

Teknik invigorasi diterapkan sesuai dengan jenis benihnya. Hal ini terkait dengan kondisi fisik benih (permeabilitas testa benih) serta komposisi kimia benih. Benih yang memiliki testa tebal lebih disarankan untuk menggunakan teknik osmoconditioning (Arief \& Koes, 2018), sedangkan benih dengan testa tipis lebih disarakankan

menggunakan matriconditioning (Priyanto, 2015; Koes \& Arief, 2010). Akan tetapi kedua teknik ini terkadang masih menemui beberapa kendala. Osmoconditioning yang diterapkan dengan cara yang tidak tepat justru akan menyebabkan imbibition damage (imbibition injury), atau kerusakan sel dalam benih akibat kesalahan dalam penerapan invigorasi (Ali \& Nisyawati, 2016; Zakia et al., 2017). Penerapan matriconditioning yang kurang tepat, juga dapat berdampak pada kekeringan media invigorasi (misalnya kelembaban media arang sekam/ serbuk gergaji kurang sempurna) dan muncul cendawan selama proses invigorasi. Untuk itu dicari sebuah modifikasi dalam melembabkan benih, menggunakan media agar. Hal ini dimaksudkan, supaya perlakuan dapat diterapkan pada semua jenis benih. Pencampuran media agar dengan arang aktif juga dimaksudkan untuk dapat memacu tumbuhnya radikula, mengurangi kejadiaan munculnya cendawan, serta dapat menyerap racun selama periode invigorasi (Husen et al., 2019). Penelitian ini bertujuan untuk mengetahui apakah media agar yang dicampur dengan arang aktif dapat digunakan sebagai alternatif cara invigorasi benih Jagung manis.

\section{METODOLOGI}

Penelitian dilaksanakan pada bulan Oktober-November 2019, bertempat di Laboratorium Benih Agronomi, Program Studi Agroteknologi, Fakultas PertanianPeternakan,Universitas Muhammadiyah Malang. Penelitian dilakukan pada benih Jagung manis varietas Talenta (DB dan IV awal sebelum perlakuan berturut-turut adalah 45\%, 25\%), menggunakan rancangan acak lengkap (RAL) sederhana. Modifikasi teknik invigorasi sebagai faktor perlakuan, terdiri atas Kontrol, benih ditumbuhkan dalam media pasir (A0), modifikasi media agar (A1), modifikasi media agar ditambah arang 
aktif (A2), modifikasi media agar yang ditumpuk/ benih diletakkan diantara media agar (A3), modifikasi media agar+arang aktif yang ditumpuk/ benih diletakkan diantara media agar+arang aktif (A4), matriconditioning menggunakan arang sekam (A5). Setiap perlakuan diulang sebanyak 3 kali. Pembuatan media agar dilakukan dengan cara mencampurkan 3,5 g serbuk agar dengan $250 \mathrm{ml}$ aquadest. Untuk perlakuan agar yang dicampur dengan arang aktif, ditambahkan sebanyak $1.3 \mathrm{~g}$ arang aktif $0,5 \%$. Media agar yang telah dipanaskan, kemudian ditiriskan dalam wadah datar hingga membeku dan dingin. Benih dalam keadaan bercoating, diberi perlakuan sesuai taraf perlakuan, kemudian disimpan dalam ruang perkecambahan suhu $20{ }^{\circ} \mathrm{C}$, selama 24 jam. Setelah 24 jam, benih dikecambahkan dalam media pasir dan diamati selama 7 hari (first count 4 dan final count 7). Variabel pengamatan yang diamati antara lain daya berkecambah/ DB (\%), potensi tumbuh maksimum/ PTM (\%), indeks vigor/ IV (\%), kecepatan tumbuh/ KCT (\%/etmal), keserempakan tumbuh $(\%)$.

$D B=\frac{K N I+K N I I}{\text { Jumlah Benih }} \times 100 \%$

Keterangan :

DB : Daya Berkecambah (\%)

KN I : Jumlah kecambah normal pada hitungan pertama

KN II : Jumlah kecambah normal pada hitungan terakhir

$\mathrm{K}_{\mathrm{CT}}=\frac{\mathrm{N} 1}{\mathrm{~W} 1}+\frac{\mathrm{N} 2}{\mathrm{~W} 2}+\ldots \frac{\mathrm{Nn}}{\mathrm{Wn}}$

Keterangan :

Kct : Kecepatan Tumbuh (\% per etmal)

$\mathrm{N}_{1}-\mathrm{Nn}$ : Pengamatan $(\mathrm{n}=1,2,3$ dan seterusnya)

$\mathrm{W}_{1-} \mathrm{Wn}$ :Waktu pengamatan $(\mathrm{n}=1,2,3$ dan seterusnya)

$$
\% I V=\frac{\text { Jumlah Kecambah Normal }}{\text { Jumlah Benih yang diuji }} \times 100 \%
$$

Keterangan :

IV :Indeks Vigor

$$
\% K s t=\frac{\begin{array}{c}
\text { Jumlah Kecambah Normal Kuat } \\
(5 \text { dan } 6 \text { hst })
\end{array}}{\text { Jumlah Benih yang diuji }} \times 100 \%
$$

Keterangan :

$\mathrm{K}_{\mathrm{ST}} \quad$ :Keserempakan Tumbuh

$$
\mathrm{PTM} \%=
$$

$\underline{\Sigma \text { Kecambah N dan Ab N sampai pengamatan ke } 7} \times 100 \%$

Keterangan:

PTM : Potensi Tumbuh Maksimum

$\mathrm{SE}(\mathrm{HST})=$ Hari awal muncul radikula

Keterangan :

SE : Seed emergence

$$
\text { Kadar air benih }=\frac{\left(M_{2}-M_{3}\right)}{\left(M_{2}-M_{1}\right)} \times 100 \%
$$

Keterangan:

$\mathrm{M}_{1} \quad$ = Berat cawan dan tutup dalam $(\mathrm{g})$

$\mathrm{M}_{2}$ = Berat cawan + benih + tutup sebelum dioven

$\mathrm{M}_{3}$ = Berat cawan + benih + tutup setelah dioven.

Data pengamatan kemudian diuji menggunakan uji $\mathrm{F}$, dan dilanjutkan dengan uji DMRT taraf 5\%.

\section{HASIL DAN PEMBAHASAN}

Pengaruh invigorasi terhadap viabilitas benih Jagung manis

Invigorasi merupakan teknik meningkatkan vigor benih dengan memanfaatkan potesnsial air dan matrik air yang rendah sehingga dapat memaksimalkan proses imbibisi. Imbibisi merupakan salah satu proses penting dalam perkecambahan benih. Imbibisi adalah proses pertama dalam tahapan perkecambahan benih, sebelum memasuki tahap selanjutnya. Berdasarkan hasil perhitungan, diketahui bahwa kadar air 
awal benih yang digunakan dalam penelitian ini sebesar $10,61 \%$. Hasil pengujian menunjukkan bahwa perlakuan

Tabel 1. Daya berkecambah (DB) dan potesi tumbuh maksimum (PTM) benih Jagung manis setelah perlakuan invigorasi

Table 1. Germination (DB) and maximum germination (PTM) in sweet corn seed after invigoration treatment

\begin{tabular}{|c|c|c|}
\hline Perlakuan & $\mathrm{DB}(\%)$ & PTM $(\%)$ \\
\hline A0 (kontrol, tanpa invigorasi) & $44,45 \quad b$ & $44,45 \quad b$ \\
\hline A1 (modifikasi agar) & 36,11 bc & 36,11 bc \\
\hline A2 (modifikasi agar + arang aktif) & 66,67 a & 66,67 a \\
\hline A3 (modifikasi agar dua layer) & $11,11 \mathrm{~d}$ & $11,11 \mathrm{~d}$ \\
\hline A4 (modifikasi agar + arang aktif dua layer) & $13,89 \mathrm{~d}$ & $13,89 \mathrm{~d}$ \\
\hline A5 (matriconditioning dengan arang sekam) & $30,55 \mathrm{c}$ & $30,55 \mathrm{c}$ \\
\hline KK & 17,82 & 17,82 \\
\hline
\end{tabular}

Keterangan: Angka-angka yang diikuti oleh huruf yang sama pada kolom yang sama menunjukkan hasil yang berbeda tidak nyata menurut uji DMRT 5\%.

Note: Means on with the same letter on the column indicates no significant difference $(p \leq 0.05)$ between the treatments using Duncan Multiple Range Test (DMRT). A0 (control, the seeds were grown in sand media), A1 (modified agar media), A2 (modified agar media added with activated charcoal), A3 (modified agar media which were stacked/ seeds were placed between agar media), A4 (modify the agar media + activated charcoal that is stacked/ the seeds are placed between the agar medium + activated charcoal), A5 (the matriconditioning uses rice husk charcoal).

Perlakuan invigorasi (Tabel 1) menggunakan modifikasi media agar yang ditambahkan dengan arang aktif (A2) menunjukkan hasil terbaik pada daya berkecambah dan potensi tumbuh maksimum benih Jagung manis. Nilai DB dan PTM menunjukan kesamaan disebabkan karena hingga akhir pengamatan (hari ke-7), tidak terdapat benih abnormal yang diamati. Benih dalam kondisi normal atau benih segar tidak tumbuh. Kondisi ini juga menunjukkan bahwa daya berkecambah benih cukup rendah mengingat kadar air yang terkandung dalam benih juga rendah. $\mathrm{Hal}$ ini tentu menyebabkan imbibisi benih berjalan dengan cukup lama, oleh karena itu teknik invigorasi yang diterapkan memberikan dampak yang signifikan. Imbibisi memegang keberhasilan perkecambahan benih. Proses imbibisi yang salah justru dapat menyebabkan kerusakan pada benih atau yang biasa disebut sebagai imbibition injury atau seed injuri. Setelah proses imbibisi selesai dan berjalan dengan baik, dilanjutkan ke tahap selanjutnya yaitu pengaktifan hormon dan enzim. Setelah hormon dan enzim aktif, kemudian terjadi proses diferensiasi sel, sehingga muncul radikula, hipokotil,dan kotiledon (Sebekti et al., 2007).

Berdasarkan data tersebut, benih Jagung yang diberi perlakuan merupakan benih yang memiliki viabilitas yang cukup rendah yaitu sebesar 44,45\%. Artinya, benih sudah memenuhi kriteria untuk diberi perlakuan invigorasi. Hasil pengujian mutu benih, menunjukkan bahwa daya berkecambah (DB) dan potensi tumbuh maksimum (PTM) memiliki nilai yang sama. Hal ini merupakan indikator bahwa selama proses perkecambahan, tidak ada benih abnormal. Seluruh benih tumbuh normal, memiliki struktur radikula, hipokotil dan kotiledon yang sehat, dalam kondisi optimum. Perlakuan modifikasi agar dan arang aktif (A2) mampu meningkatkan viabilitas benih sebesar 22,22 \% 
dibanding dengan kontrol (tanpa invigorasi).

Pengaruh invigorasi terhadap vigor benih Jagung manis

Viabilitas merupakan indikator benih berkecambah dengan baik dalam kondisi optimum, vigor benih merupakan indikator perkecambahan benih tumbuh normal pada kondisi sub optimum (Ilyas, 2012). Perhitungan vigor benih mengacu pada perkecambahan benih saat first count dan final count (ISTA, 2014). Hasil pengujian menunjukkan bahwa perlakuan memberikan pengaruh yang signifikan pada seluruh variabel pengamatan, kecuali variabel keserempakan tumbuh (KST).

Tabel 2. Indeks vigor (IV), kecepatan tumbuh $\left(\mathrm{K}_{\mathrm{CT}}\right)$, dan keserempakan tumbuh $\left(\mathrm{K}_{\mathrm{ST}}\right)$ benih Jagung manis setelah perlakuan invigorasi

Table 2. Vigor Index (IV) and germination speed $\left(K_{C T}\right)$, and simultaneously increase $\left(K_{S T}\right)$ in sweet corn seed after invigoration treatment

\begin{tabular}{|c|c|c|c|c|c|c|}
\hline Perlakuan & \multicolumn{2}{|c|}{$\mathrm{IV}^{*}(\%)$} & \multicolumn{2}{|c|}{$\mathrm{K}_{\mathrm{CT}} *(\% /$ etmal $)$} & \multicolumn{2}{|c|}{$\mathrm{K}_{\mathrm{ST}} * *(\%)$} \\
\hline A0 (kontrol, tanpa invigorasi) & 22,22 & $\mathrm{~b}$ & 10,87 & $\mathrm{~b}$ & 6,49 & $\mathrm{a}$ \\
\hline A1 (modifikasi agar) & 25 & $a b$ & 12,14 & $\mathrm{~b}$ & 2,78 & $\mathrm{a}$ \\
\hline A2 (modifikasi agar + arang aktif) & 41,67 & $\mathrm{a}$ & 20,36 & $\mathrm{a}$ & 7,87 & $\mathrm{a}$ \\
\hline $\begin{array}{l}\text { A3 (modifikasi agar dua layer) } \\
\text { A4 (modifikasi agar }+ \text { arang aktif dua }\end{array}$ & 5,56 & $\mathrm{c}$ & 2,48 & $\mathrm{c}$ & 1,4 & $\mathrm{a}$ \\
\hline layer) & 8,34 & $\mathrm{c}$ & 3,96 & $\mathrm{c}$ & 3,71 & a \\
\hline $\begin{array}{l}\text { A5 (matriconditioning dengan arang } \\
\text { sekam) }\end{array}$ & 19,44 & $\mathrm{~b}$ & 9,22 & $\mathrm{~b}$ & 5,1 & $\mathrm{a}$ \\
\hline KK & 21,59 & & 12,77 & & 18,45 & \\
\hline
\end{tabular}

Keterangan: Angka-angka yang diikuti oleh huruf yang sama pada kolom yang sama menunjukkan hasil yang berbeda tidak nyata menurut uji DMRT 5\%.*) Sebelum diolah data ditransformasikan dengan rumus $\sqrt{x}+0.5$.**) Sebelum diolah data ditransformasikan dengan rumus $\sqrt{x}+8$.

Note: Means on with the same letter on the column indicates no significant difference $(\mathrm{p} \leq 0.05)$ between the treatments using Duncan Multiple Range Test (DMRT). *) Before being processed, the data is transformed using the $\sqrt{x}+0.5$ equation. *) Before being processed, the data is transformed using the $\sqrt{x}+8$ equation. Hst/ dap: day after planting. A0 (control, the seeds were grown in sand media), A1 (modified agar media), A2 (modified agar media added with activated charcoal), A3 (modified agar media which were stacked/ seeds were placed between agar media), A4 (modify the agar media + activated charcoal that is stacked/ the seeds are placed between the agar medium + activated charcoal), A5 (the matriconditioning uses rice husk charcoal).

Pengaruh perlakuan invigorasi terhadap vigor benih Jagung manis ditunjukkan oleh Tabel 2. Berdasarkan hasil analisis diketahui bahwa perlakuan invigorasi menggunakan modifikasi media agar yang ditambahkan dengan arang aktif (A2) mampu meningkatkan indeks vigor (IV) dan kecepatan tumbuh $\left(\mathrm{K}_{\mathrm{CT}}\right)$ benih Jagung manis dibanding kontrol tanpa perlakuan. IV dan $\mathrm{K}_{\mathrm{CT}}$ perlakuan A2 lebih baik dibanding kontrol, merupakan indikator bahwa melalui invigorasi proses imbibisi benih berjalan dengan baik dan optimal. Suhu perlakuan $20{ }^{\circ} \mathrm{C}$ merupakan suhu lingkungan yang mendukung benih berimbibisi secara perlahan, sehingga tidak menyebabkan kerusakan sel dalam benih.

Persentase indeks vigor benih yang tinggi menunjukkan bahwa benih memiliki kemampuan tumbuh yang baik. Indeks vigor dinilai dari banyaknya jumlah kecambah normal saat first count. Artinya jika benih tumbuh dengan baik pada fisrt count (Jagung 5 hst), maka Jagung memiliki daya tumbuh yang baik. 
Pengujian secara laboratorium merupakan pengujian yang menggambarkan kondisi optimum, sehingga jika Jagung dapat berkecambah cukup baik sampai dengan hari hitungan pertama, maka benih Jagung nantinya memiliki kemampuan tumbuh yang optimal meskipun dalam kondisi sup obtimum.

Beberapa teknik invigorasi yang telah diterapkan selama ini, antara lain, menggunakan media cair (hydropriming), air dengan potensial rendah (priming/ osmoconditioning), dan matriconditioning (padatan lembab, matriks rendah) (Khan et al., 2017). Berbagai teknik invigorasi tersebut menunjukkan hasil yang baik bagi masing-masing jenis tanaman. Atau dengan kata lain setiap benih tidak dapat dipukul rata untuk diberikan perlakuan invigorasi dengan berbagai teknik apapun, beberapa jenis benih hanya dapat menerima perlakuan teknik invigorasi tertentu. Hal ini disebabkan permeabilitas benih setiap komodias tanaman berbedabeda. Tebal dan tipis testa, serta dominasi senyawa yang membentuk bagian testa (lipid, protein, atau karbohidrat) akan menyebabkan laju imbibisi juga berbeda. Hal ini juga akan berpengaruh terhadap lama waktu yang dibutuhkan untuk proses imbibisi. Disamping itu kadar air awal benih juga akan mempengaruhi laju imbibisi. Kadar air penyimpanan benih yang sangat rendah (dibawah $14 \%$ untuk benih ortodok) akan menyebabkan waktu yang dibutuhkan benih untuk ber-imbibisi maksimum juga relatif lama.

Beberapa hasil penelitian menunjukkan bahwa teknik invigorasi secara priming akan memberikan hasil bagus jika dilakukan dengan benar. Akan tetapi, beberapa pengujian benih menunjukkan bahwa perlakuan priming (hydropriming) yang kurang tepat, mengalami kesalahan dalam cara memberi perlakuan, kadar air dalam benih sangat rendah (tanpa ada perlakuan khusus, proses mendiamkan dalam suhu ruang atau diangin-anginkan) justru akan menyebabkan kerusakan pada benih (Afzal et al., 2002). Menurut (FinchSavage et al., 2004), perlakuan priming pada Jagung dapat memberikan respon positif, netral atau bahkan negatif. Perlakuan negatif disebabkan adanya kerusakan selama proses imbibisi saat pemberian perlakuan invigorasi. Kerusakan terjadi karena saat benih yang telah disimpan, memiliki kadar air sangat rendah, kemudian dimasukkan dalam air, secara langsung, maka masukkan air saat proses imbibisi berjalan sangat cepat. Kecepatan imbibisi yang tidak terkontrol justru akan menyebabkan kerusakan dalam membran sel, sehingga benih akan semakin membutuhkan waktu yang lama untuk berkecambah. Kerusakan inilah yang kemudian disebut sebagai imbibition injury atau seed injury. Invigorasi melalui matriconditioning memungkinkan benih dengan kadar air sangat rendah melalui proses imbibisi benih dengan baik. Hal ini disebabkan media padat yang dilembabkan, menjadi sarana air untuk masuk dalam benih melalui testa secara terkontrol. Imbibisi yang terkotrol dapat memaksimalkan proses perkecambahan benih, sehingga menghasilkan nilai viogr benih yang tinggi.

Hasil pengujian menunjukkan bahwa perlakuan modifikasi agar dan arang aktif (A2) mampu mempercepat perkecambahan, ditunjukkan oleh data $\mathrm{T}_{50}$, meskipun data $\mathrm{SE}$ tidak berbeda nyata dengan kontrol. Seed emerge dan T50 merupakan variabel vigor benih. 
Tabel 3. Seed emergence (SE) dan $\mathrm{T}_{50}$ benih Jagung manis setelah perlakuan invigorasi Table 3. Seed emergence (SE) dan $T_{50}$ in sweet corn seed after invigoration treatment

\begin{tabular}{|c|c|c|}
\hline Perlakuan & $\mathrm{SE}^{*}(\mathrm{hst})$ & T50 (hst \\
\hline A0 (kontrol, tanpa invigorasi) & $2 \mathrm{~b}$ & $8 \mathrm{~cd}$ \\
\hline A1 (modifikasi agar) & $2 b$ & $9 \mathrm{bc}$ \\
\hline A2 (modifikasi agar + arang aktif) & $2 \mathrm{~b}$ & $6 \mathrm{~d}$ \\
\hline A3 (modifikasi agar dua layer) & $4 \mathrm{a}$ & $14 \mathrm{a}$ \\
\hline A4 (modifikasi agar + arang aktif dua layer) & $4 a b$ & $14 \mathrm{a}$ \\
\hline A5 (matriconditioning dengan arang sekam) & $3 \mathrm{ab}$ & $11 \mathrm{~b}$ \\
\hline KK & 15,15 & 10,15 \\
\hline
\end{tabular}

Keterangan: Angka-angka yang diikuti oleh huruf yang sama pada kolom yang sama menunjukkan hasil yang berbeda tidak nyata menurut uji DMRT 5\%. *) Sebelum diolah data ditransformasikan dengan rumus $\sqrt{x}$. Hst: hari setelah tanam.

Note: Means on with the same letter on the column indicates no significant difference $(\mathrm{p} \leq 0.05)$ between the treatments using Duncan Multiple Range Test (DMRT). *) Before being processed, the data is transformed using the $\sqrt{x}$ equation. Hst/ dap: day after planting. A0 (control, the seeds were grown in sand media), A1 (modified agar media), A2 (modified agar media added with activated charcoal), A3 (modified agar media which were stacked/ seeds were placed between agar media), A4 (modify the agar media + activated charcoal that is stacked/ the seeds are placed between the agar medium + activated charcoal), A5 (the matriconditioning uses rice husk charcoal).

Variabel seed emergence dan T50 termasuk dalam variabel vigor benih. Seed emergence menunjukkan bahwa radikula benih siap-siap untuk muncul dan menembus testa benih. Semakin cepat waktu yang dibutuhkan benih untuk bisa dikategorikan seed emergence, maka semakin baik teknik invigorasi yang diterapkan. Seed emergence mengindikasikan bahwa perkecambahan benih siap untuk dimulai. Variabel T50 merupakan variabel yang menunjukkan hari ke berapa benih tumbuh $50 \%$.
Semakin cepat waktu yang ditempuh benih untuk mencapai T50, maka secara tidak langsung menjadi indikator, benih memiliki vigor tinggi.

Hasil korelasi setiap variabel ditunjukkan oleh Tabel 3. Seluruh variabel memiliki korelasi yang kuat, kecuali variabel keserempakan tumbuh (KST). Hal ini disebabkan nilai KST didapatkan dari nilai tengah antara first count dan final count. Apabila nilai rendah, berarti keserempakan tumbuh rendah.

Tabel 4. Korelasi antar variabel pengamatan benih Jagung manis setelah perlakuan invigorasi

Table 4. Correlation between variables of sweet corn seeds after invigoration treatment

\begin{tabular}{llllllll}
\hline & DB & PTM & IV & KCT & KST & SE & T50 \\
\hline DB & 1 & & & & & & \\
PTM & $1^{*}$ & 1 & & & & & \\
IV & 0,884 & 0,884 & 1 & & & & \\
KCT & 0,948 & 0,948 & 0,970 & 1 & & & \\
KST & 0,330 & 0,330 & 0,023 & 0,211 & 1 & & \\
SE & $-0,668$ & $-0,668$ & $-0,772$ & $-0,752$ & $-0,046$ & 1 & \\
T50 & $-0,957$ & $-0,957$ & $-0,835$ & $-0,895$ & $-0,315$ & 0,707 & 1 \\
\hline
\end{tabular}


Korelasi seed emerge dan T50 terhadap seluruh variabel menunjukkan nilai yang cukup signifikan. Kedua variabel ini berkorelasi negatif, karena semakin kecil nilai seed emerge atau pun T50, menunjukkan vigor benih yang semakin tinggi. Berdasarkan data tersebut juga menujukkan bahwa variabel daya berkecambah (DB), potensi tumbuh maksimum (PTM), indeks vigor (IV), kecepatan tumbuh (KCT), dan T50 berkorelasi tinggi, sehingga kesimpulan antar data yang didapatkan cukup signifikan.

Perlakuan invigorasi bertujuan untuk memobilisasi sumber energi yang berasal dari dalam endosperm benih, dikombinasikan dengan energi yang berasal dari luar benih (lingkungan tumbuh benih) untuk menghasilkan pertanaman dan hasil yang optimal. Invigorasi dapat pula disebut sebagai conditioning atau priming. Beberapa metode invigorasi yaitu hydropriming atau lebih dikenal dengan metode hydrasidehidrasi, osmoconditioning atau osmopriming (disingkat priming), dan matriconditioning yang juga merupakan solid matrix priming. Penerapan media agar sebagai media invigorasi, merupakan pendekatan gabungan dua metode, baik osmoconditioning dan matriconditioning. Agar merupakan senyawa ester asam sulfat dari senyawa galaktan, tidak larut dalam air dingin, tetapi larut dalam air panas dengan membentuk gel (Distantina et al., 2012).

Penggunaan media agar sebagai salah satu teknik dalam invigorasi, adalah terkait agar yang bersifat sineresis. Sineresis merupakan peristiwa keluarnya atau merembesnya cairan dari suatu gel. Hal ini memungkinkan bahwa air yang keluar dari agar secara perlahan akan diserap oleh benih. Air yang diserap secara perlahan oleh benih akan menyebabkan proses imbibisi berjalan secara terkontrol. Bagian ini yang merupakan modifikasi teknik invigorasi dengan menggabungkn antara priming (cair) dan matriconditioning (padat lembab).

Penambahan arang aktif dalam media agar bertujuan untuk mendukung pertumbuhan akar, memacu perakaran lebih cepat. Disamping itu arang aktif juga dapat mengurangi kejadian jamur di permukaan agar selama proses invigorasi 24 jam. Arak aktif yang bersifat basa juga akan memacu perkecambahan benih Jagung. Karakteristik enzim amilase dari kecambah Jagung optimum pada $\mathrm{pH} 9$ (Bahri et al., 2012).

Berdasarkan

pengamatan, invigorasi menggunakan media agar tanpa arang aktif memberikan hasil yang kurang baik. Hal ini diduga disebabkan karena warna agar yang putih/ transparan, menyebabkan cahaya/ lampu tetap dapat masuk dalam benih. Cahaya dibutuhkan dalam proses perkecambahan dengan jumlah yang pas. Beberapa jenis benih justru menghendaki kondisi gelap yang lebih dominan dibanding dengan kondisi terang. Aktifitas enzim yang peka terhadap cahaya berperan dalam perkecambahan benih, dan ditunjukkan dari lama benih berkecambah. Keberadaan hormon auksin, sitokinin, dan giberelin juga harus seimbang, sehingga mampu menginduksi perkecambahan banih. Hormon sitokinin mengambil peran penting dalam perkecambahan Jagung (Smith \& Van Staden, 1978). Hormon ini terdeteksi semakin meningkat aktivitasnya dalam poros embrio, seiring dengan waktu imbibisi benih Jagung. Hartanto et al., (2009), juga menjelaskan fungsi dalam menginduksi pembelahan sel, mempengaruhi pertambahan tunas dan akar, serta meningkatkan daya resistensi terhadap pengaruh yang merugikan seperti suhu rendah.

Disisi lain, untuk perlakuan media agar dengan menerapkan agar dua lapis menghimpit benih, juga menunjukkan 
hasil yang kurang baik. Hal ini disebabkan oleh pasokan $\mathrm{O}_{2}$ bagi benih untuk mendukung proses respirasi menjadi terhambat. Respirasi merupakan katabolisme, yang dibutuhkan untuk keberlangsungan sel dalam benih. Hasil penelitian (Woodstock \& Grabe, 1967), menjelasakan bahwa selama periode imbibisi berlangsung, $\mathrm{O}_{2}$ yang diserap oleh Jagung juga semakin meningkat. Jika respirasi berjalan lancar, maka proses perkecambahan juga berjalan dengan baik. (Finch-Savage et al., 2004) dalam penelitiannya juga menjelaskan bahwa kegagalan perlakuan priming Jagung terjadi akibat reaksi hipoksia. Hipoksia merupakan kejadian kekurangan $\mathrm{O}_{2}$ oleh benih yang justru akan menghambat perkecambahan dan pertumbuhan tanaman. Dalam kasus perlakuan media agar yang ditumpuk (2 layer), menjelaskan bahwa kemungkinan besar reaksi hipoksia terjadi selama proses imbibisi benih.

Perlakuan modifikasi teknik invigorasi dilakukan dengan berbagai cara, namun perlakuan modifikasi agar dan arang aktif (A2) menunjukkan hasil yang baik. Hal ini diduga perlakuan A2, mampu memfasilitasi benih untuk dapat berkecambah dengan baik, karena kondisi gelap yang secara tidak langsung dapat merangsang tumbuhnya radikula. Diamping itu aerasi yang baik, juga menyebabkan proses imbibisi benih berjalan edngan baik, dan tidak mengganggu aktifitas benih untuk respirasi.

\section{KESIMPULAN}

Modifikasi metode invigorasi menggunakan agar dan arang aktif dapat dijadikan sebagai alternatif perlakuan invigorasi terhadap benih Jagung. Melalui invigorasi ini, viabilitas dan vigor benih Jagung masing-masing meningkat sebesar $22,22 \%$ dan $19,45 \%$ dibanding kontrol tanpa perlakuan.

\section{DAFTAR PUSTAKA}

Afzal, I., Basra, S. M. A., \& Ahmad, N. EQ (2002). Effect of priming and growth regulator treatment on emergence and seedling growth of hybrid maize (Zea mays). International Journal of Agriculture \& Biology, 4(2), 303306.

Ali A., \& N. (2016). Viabilitas biji

畺 belimbing (Averrhoa carambola L.) kultivar "Dewa Baru" asal kecamatan cimanggis, Depok pada berbagai suhu penyimpanan. Jurnal Pro-Life, 3(3), 195-211.

Arief R., Koes F., \& H. G. (2018). Evaluasi terhadap beberapa invigorasi benih Jagung (Zea mays L.) yang disimpan. Seminar Nasional. Balai Besar Pengkajian Dan Pengembangan Teknologi Pertanian, 537-541.

[BSN] Badan Standarisasi Nasional, 期 (2008). SNI 01-3920-2013. Mutu Jagung Pipilan

Bahri, S., Mirzan, M., \& Hasan, M. 的 (2012). Karakterisasi Enzim Amilase Dari Kecambah Biji Jagung Ketan ( Zea mays ceratina L .). Jurnal Natural Science, 1(1), 132-143.

Distantina, S., Rachmawati, D., \& Eka, L. EQ (2012). Pengaruh Konsentrasi dan Jenis Larutan Perendaman terhadap Kecepatan Ekstraksi dan Sifat Gel Agar-agar dari Rumput Laut Gracilaria verrucosa. Jurnal Rekayasa Proses, 2(1), 10-14.

Finch-Savage, W. E., Dent, K. C., \& 程 Clark, L. J. (2004). Soak conditions and temperature following sowing influence the response of maize (Zea mays L.) seeds to on-farm priming (pre-sowing seed soak). Field Crops 
Research, 90(2-3), 361-374.

Hariadi, Husen, Y., Riniarti, M., \& 尌 Hapsoro, D. (2019). Pengaruh arang aktif, benziladenin, dan kinetin terhadap pertumbuhan tunas jati solomon (Tectona grandis Linn. F) in vitro. Jurnal Biologi Eksperimen Dan Keanekaragaman Hayati, 5(2), 21-30.

Harris, D., A. Rashid, P.A. Hollington, L.Jasi., \& C. R. (2004). Prospects of improving maize yield with " onfarm seed priming" ( and A. F. . P. (ed) S. maize production system for N. N.P Rajbhandari, J.J. Ranson, K. Adhikari (ed.)). NARC and CIMMYT.

Hartanto, A., Haris, A., \& Widodo, D. S. 的 (2009). Pengaruh Kalsium, Hormon Auksin, Giberellin dan Sitokinin terhadap Pertumbuhan dan Perkembangan Tanaman Jagung. Jurnal Kimia Sains Dan Aplikasi, 12(3), 72-75.

Ilyas, S. (2012). Ilmu dan Teknologi Benih 程 (Teori dan Hasil-hasil Penelitian). IPB Press.

Ilyas, S, G.A.K. Sutariati, F.C. Suwarno, E \& S. (2002). Matriconditioning improved quality and protein level of medium vigor hot pepper seed. Seed Technol., 24, 65-75.

[ISTA] International Seed Testing 琶 Association. (2014). International Rules for Seed Testing.

Kementan (2013) Data Statistik 㰯 Ketahanan Pangan tahun 2012.Jakarta (ID):Badan Ketahanan Pangan Kementerian Pertanian 2013. Khan, A. Z., Shah, T., Khan, S., Rehman,
A., Akbar, H., Muhammad, A., \& Khalil, S. K. (2017). Influence of Seed Invigoration Techniques on Germination and Seedling Vigor of Maize (Zea mays L.). Cercetari Agronomice in Moldova, 50(3), 6170 .

Khan AA, Willy, \& S. (1992). Preplant EQ physiological seed conditioning. Journal Plant Physiology, 131-181.

Koes, F., \& Arief, R. (2010). Deteksi dini 副 mutu dan ketahanan simpan benih jagung hibrida F1 Bima 5 melalui uji pengusangan cepat (AAT). Prosiding Pekan Serealia Nasional, 455-463.

Koes F., \& Arief R. 2011. Pengaruh 尌 perlakuan matriconditioning terhadap viabilitas dan vigor benih Jagung. Seminar Nasional Serealia. 548-555

Nuraini, A., Sumadi, S., Kadapi, M., 基 Wahyudin, A., Ruswandi, D., \& Anindya, M. N. (2018). Evaluasi ketahanan simpan enam belas genotip benih jagung hibrida Unpad pada periode simpan empat bulan. Kultivasi, 17(1), 568-575.

Panikkai, S. (2017). Analisis Ketersediaan EQ Jagung Nasional Menuju Swasembada Dengan Pendekatan Model Dinamik. Informatika Pertanian, 26(1), 41.

Priyanto, Y. A. (2015). Vaibility of 的 soybean seeds (Glycine max L. Merril) by matriconditioning and osmoconditioning invigoration. Jurnal Hexagro. 1(1):1-10.

Sebekti NA., Syafruddin, Efendi R., \& S. EQ S. (2007). Jagung: Teknik Produksi dan Pengembangan. Balai Penelitian Tanaman Serealia. 
Smith, A. R., \& Van Staden, J. (1978).

E. Changes in endogenous cytokinin levels in kernels of Zea mays L. during imbibition and germination. Journal of Experimental Botany, 29(5), 1067-1075.

Taini ZF, MR Suhartanto, Z. (2019).

期 Pemanfaatan alat pengusangan cepat menggunakan etanol untuk pendugaan cigor daya simpan benih Jagung (Zea mays L.). Bul Agrohorti, 7(2), 230-237.

Woodstock, L. W., \& Grabe, D. F. (1967).

尌 Relationships Between Seed Respiration During Imbibition and Subsequent Seedling Growth in Zea mays L. . Plant Physiology, 42(8), 1071-1076.

Zakia, A., Ilyas, S., Budiman, C., , S., \& 琶 Manohara, D. (2017). Peningkatan Pertumbuhan Tanaman Cabai dan Pengendalian Busuk Phytophthora melalui Biopriming Benih dengan Rizobakteri Asal Pertanaman Cabai Jawa Timur. Jurnal Hortikultura Indonesia, 8(3), 171. 